\title{
Lack of Correlation between Ammonium Accumulation and Survival of Transgenic Birch Plants with Pine Cytosolic Glutamine Synthetase Gene after "Basta" Herbicide Treatment
}

\author{
Vadim Lebedev, Vyacheslav Faskhiev, and Konstantin Shestibratov \\ Branch of Shemyakin and Ovchinnikov Institute of Bioorganic Chemistry, Russian Academy of Sciences, Science Avenue 6, Pushchino, \\ Moscow Region 142290, Russia \\ Correspondence should be addressed to Vadim Lebedev; vglebedev@mail.ru
}

Received 30 October 2015; Revised 8 December 2015; Accepted 9 December 2015

Academic Editor: Shamsul Hayat

Copyright (c) 2015 Vadim Lebedev et al. This is an open access article distributed under the Creative Commons Attribution License, which permits unrestricted use, distribution, and reproduction in any medium, provided the original work is properly cited.

\begin{abstract}
Transformation of plants with genes encoding a glutamine synthetase (GS), a key nitrogen metabolism enzyme, is usually used to increase productivity. However, overexpression of these genes may increase resistance to phosphinothricin (PPT) that irreversibly inhibits GS causing ammonium accumulation in plant tissues. Transgenic plants of two birch (Betula pubescens) genotypes expressing a pine cytosolic GS gene were used for studying the PPT effect on trees. Two control and 8 transgenic lines were treated with herbicide "Basta" at dose equivalent to 2.5 and $5 \mathrm{Lha}^{-1}$. Necrosis and abscission of leaves occurred irrespective of a transgenic status or the treatment dose. Ammonium content in leaf tissue in 3 days after the $5 \mathrm{Lha}^{-1}$ treatment was substantially increased in all plants, 3.2-16.0 times depending on line. After the $2.5 \mathrm{Lha}^{-1}$ treatment, ammonium content in three transgenic lines was not different from that in control variant sprayed with water. The herbicide treatment caused more prominent desiccation in the bp3f1 genotype nontransgenic plants as compared to transgenic plants, but not in the bp4a genotype. Lack of correlation between ammonium levels and survival of transgenic plants suggests that ammonium toxicity is not a main reason for the birch plant death after the PPT treatment.
\end{abstract}

\section{Introduction}

Increasing productivity of forest plantations is one of the main directions of the genetic engineering of forest trees. To achieve this goal, several approaches are used. One of these approaches is increasing the efficiency of assimilation of nutrients, nitrogen in particular. This method is of special interest for the forest species of the temperate climate as the boreal forests are strongly nitrogen limited ecosystems [1]. To improve nitrogen assimilation, transfer of the gene encoding glutamine synthetase, one of key nitrogen metabolism enzymes in plants, is used. The glutamine synthetase plays a central role in nitrogen metabolism as products of a GS/GOGAT cycle, glutamate and glutamine, are precursors for all the organic nitrogen compounds in plants [2]. However, though this approach is promising, there are few studies about transfer of the GS gene into woody species; reports for a Populus tremula $\times$ P. alba hybrid [3] and for an European aspen (P. tremula) are known [4]. Another problem in forestry is weed control, and herbicide resistant trees could be used to improve productivity and reduce the costs of forest management through to the first and second years after tree establishment [5]. However plants expressing an additional glutamine synthetase gene may possess an increased resistance to phosphinothricin (PPT, ammonium glufosinate) based herbicides. PPT is a structural glutamate analog that irreversibly inhibits GS activity [6]. A large number of studies carried out on herbaceous plants do not allow determining conclusively the reasons for the plant death caused by the PPT treatment. The close correlation between the free ammonia content and the herbicidal activity indicated that the toxicity of accumulated ammonia is a primary factor to the herbicidal activity [7]. On the other hand, Wendler et al. [8] demonstrated that $\mathrm{NH}_{4}{ }^{+}$accumulation in Sinapis alba plants cannot be the primary cause for PPT-related inhibition of photosynthesis. Analogous studies were not performed for 
woody plants. We first evaluated PPT effect on transgenic birch plants with the cytosolic GS gene from the Scots pine. Transgenic plants were treated with different doses of the "Basta" herbicide under open air conditions and resistance level and the foliar ammonium content were measured.

\section{Materials and Methods}

Transgenic plants were obtained via Agrobacterium-mediated transformation of two genotypes, bp3f1 and bp4a, of downy birch (Betula pubescens Ehrh.) with pGS vector [9]. This vector contains GS1 gene encoding the cytosolic form of GS from the Scots pine (Pinus sylvestris L.) under the control of a CaMV 35 S promoter, and an nptII gene under the control of a nos promoter. The transformation protocol was previously published by Lebedev et al. [9]. Ten lines (two nontransgenic controls, five bp3f1-based transgenic lines, and three bp4abased lines) were propagated in vitro. After adaptation to the greenhouse conditions, they were transplanted into 1-liter pots with peat: perlite $(3: 1, \mathrm{v} / \mathrm{v})$ substrate and transferred to outdoors.

Total RNA was extracted from leaves of birch plants as described by Chang et al. [10]. The mixture of $1-2 \mu \mathrm{g}$ of RNA, $0.5 \mu \mathrm{g}$ of oligo-dT primer, and $10 \mathrm{U}$ of RNAse inhibitor (SibEnzyme, Russia) was heated at $70^{\circ} \mathrm{C}$ for $5 \mathrm{~min}$ and then chilled on ice with the subsequent addition of $0.4 \mathrm{mM}$ dNTP and $4 \mathrm{U} \mu \mathrm{L}^{-1} \mathrm{M}-\mathrm{MuLV}$ reverse transcriptase (SibEnzyme, Russia). The mixture was incubated at $37^{\circ} \mathrm{C}$ for $1.5 \mathrm{~h}$ and then heated at $70^{\circ} \mathrm{C}$ for $15 \mathrm{~min}$. PCR mixture $(12 \mu \mathrm{L})$ included ScreenMix-HS (Evrogen, Russia) and $0.8 \mathrm{mM}$ following primers:

GS-up 1, 5' -TATTAACAGACCTTCTCAACCTTGA-3'.

GS-low 1, 5'-CTGATATTGATTCCTGAATAGAGAC-3'.

Actin 1-up, $5^{\prime}$-TATGCCCTCCCACATGCCAT-3'. Actin 1-low, $5^{\prime}$-CATCTGCTGGAAGGTGCTGA-3'.

Thermal cycling conditions were as follows: $95^{\circ} \mathrm{C}$ for $5 \mathrm{~min}$, followed by $31 \mathrm{cycles}$ of $95^{\circ} \mathrm{C}$ for $45 \mathrm{sec}, 59^{\circ} \mathrm{C}$ for $30 \mathrm{sec}$, and $72^{\circ} \mathrm{C}$ for $1 \mathrm{~min}$, with a final extension at $72^{\circ} \mathrm{C}$ for $10 \mathrm{~min}$.

The plants $40-50 \mathrm{~cm}$ in length were sprayed with water, $0.5 \%$ or $1 \%$ solution $(\mathrm{v} / \mathrm{v})$ of the "Basta" herbicide in water (Bayer CropScience, $150 \mathrm{gL}^{-1} \mathrm{PPT}$ ) in the dose equivalent to $2.5 \mathrm{Lha}^{-1}$ (desiccation dose) or $5 \mathrm{Lha}^{-1}$ (normal field dose). Four plants were used for each tested line. Plants were observed for symptoms in 3, 7, 14, and 28 days after the treatment. Leaf samples were taken at the day of the treatment and in 3 days after the treatment for measuring levels of ammonium nitrogen and water content. Extraction was carried out according to De Block et al. [11]. Ammonium nitrogen content was measured according to Weatherburn [12]. Water content was determined by drying for $24 \mathrm{~h}$ at $105^{\circ} \mathrm{C}$. All data were subjected to analysis of variance (ANOVA). Differences between means were assessed by Duncan's multiple range test. The correlations between ammonium accumulation and survival of transgenic plants were calculated based on Pearson correlation. Statistical analysis was made using Statistica 6.1 software (StatSoft).

\section{Results}

To analyze the expression of the GS1 gene before herbicide treatment, RT-PCR was performed with total RNA samples extracted from birch leaf tissue. As illustrated in Figures 1(a) and 1(b), the GS1 transcript was accumulated in all of the analyzed transgenic lines, including five bp3f1-based lines and three bp $4 a-b a s e d$ lines.

About $40-60 \%$ of leaf area was necrotized in the control and transgenic birch plants in 3 days after the treatment with 2.5 and $5 \mathrm{Lha}^{-1}$ of the "Basta" herbicide. In 7 days after the treatment, necrosis was observed in $75-100 \%$ of the leaf area in all the plants. Furthermore, shoot tip necrosis was observed in all the nontransgenic control plants. In the plants carrying the pine GS gene, all the shoot tips were necrotized after the $5 \mathrm{Lha}^{-1}$ herbicide treatment, while several plants survived and continued to grow after the $2.5 \mathrm{Lha}^{-1}$ treatment. In 28 days after the treatment, leaves of all the plants were completely necrotized and fell, but 10 plants of 6 lines with the pine GS gene (F14GS2b, F14GS2c, F14GS9b, and all the bp4a genotype-based lines) that were treated with $2.5 \mathrm{Lha}^{-1}$ dose have survived: growth of the shoot tips continued or axillary buds started growing in these plants.

Analysis of ammonium content has shown that the herbicide treatment caused a strong increase in its concentration in control birch plants, 4.6-5.8 times as compared to the basal levels (Figure 2). Treatment of plants with a normal field dose of $5 \mathrm{Lha}^{-1}$ caused similar reaction in all lines with the GS gene, significant increase in the ammonium levels (3.6-16.0 times depending on the line). P17GS1a line stood out against the others; ammonium content increased to $139.8 \mu \mathrm{g} \mathrm{NH}_{4}{ }^{+} \mathrm{g} \mathrm{FW}^{-1}$, while in the others it did not exceed $80 \mu \mathrm{g} \mathrm{NH}_{4}{ }^{+} \mathrm{g} \mathrm{FW}^{-1}$. Treatment of plants with $2.5 \mathrm{Lha}^{-1}$ dose caused the ammonium accumulation to a lesser extent, to 8 times as much as in the control. Reaction of plants was also various; in three lines, F14GS2b, F14GS8b, and P17GS2, an increase in the ammonium levels in leaf tissue did not differ significantly from that in control water-treated variant. In most of the lines, increase in the treatment dose led to increase of the ammonium content in the leaf tissue. However, in two nontransgenic lines and F14GS16b line, opposite results were observed (Figure 2).

Analysis of water content has shown that the herbicide treatment led to desiccation of the leaf tissue in control and transgenic lines (Table 1). Before the treatment, water content in all the plants was approximately $55 \pm 2 \%$ (data not shown). After the water spraying, water content did not change significantly and remained within the same limits, 53-57\%. In 3 days after the herbicide treatment, water content has dropped to $31-34 \%$ in the control bp3f1 line, regardless of the applied dose. In the bp3f1-based transgenic lines, desiccation was significantly lower in comparison with parental genotype treatment with $2.5 \mathrm{Lha}^{-1}$ dose which caused reduction in water content to $42-47 \%$. $5 \mathrm{Lha}^{-1}$ treatment almost did not lead to further water loss in F14GS2b line, while in other bp3f1-based 


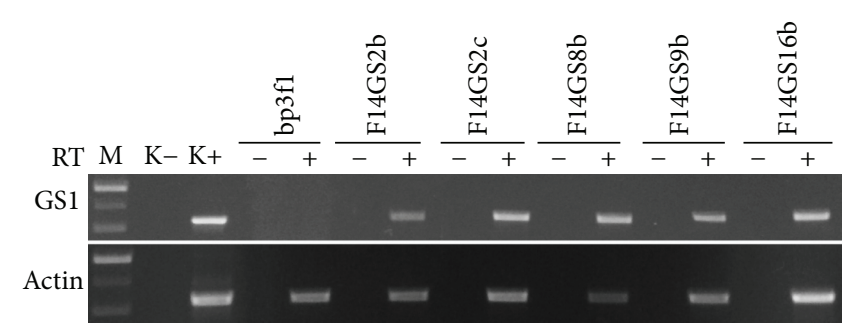

(a)

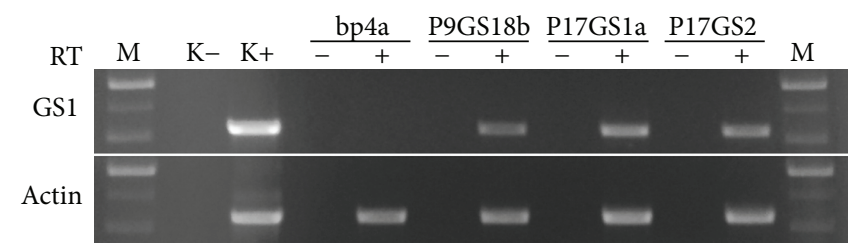

(b)

FIGURE 1: RT-PCR analysis of GS1 mRNA expression in birch leaves. (a) bp3f1 genotype-based lines. (b) bp4a genotype-based lines. RT-PCR was performed in the absence (-) or the presence $(+)$ of reverse transcriptase to control for DNA contamination. The actin gene was used as an internal control. M: markers, K-: water, and K+: pGS (GS1) or nontransgenic birch plants (actin).

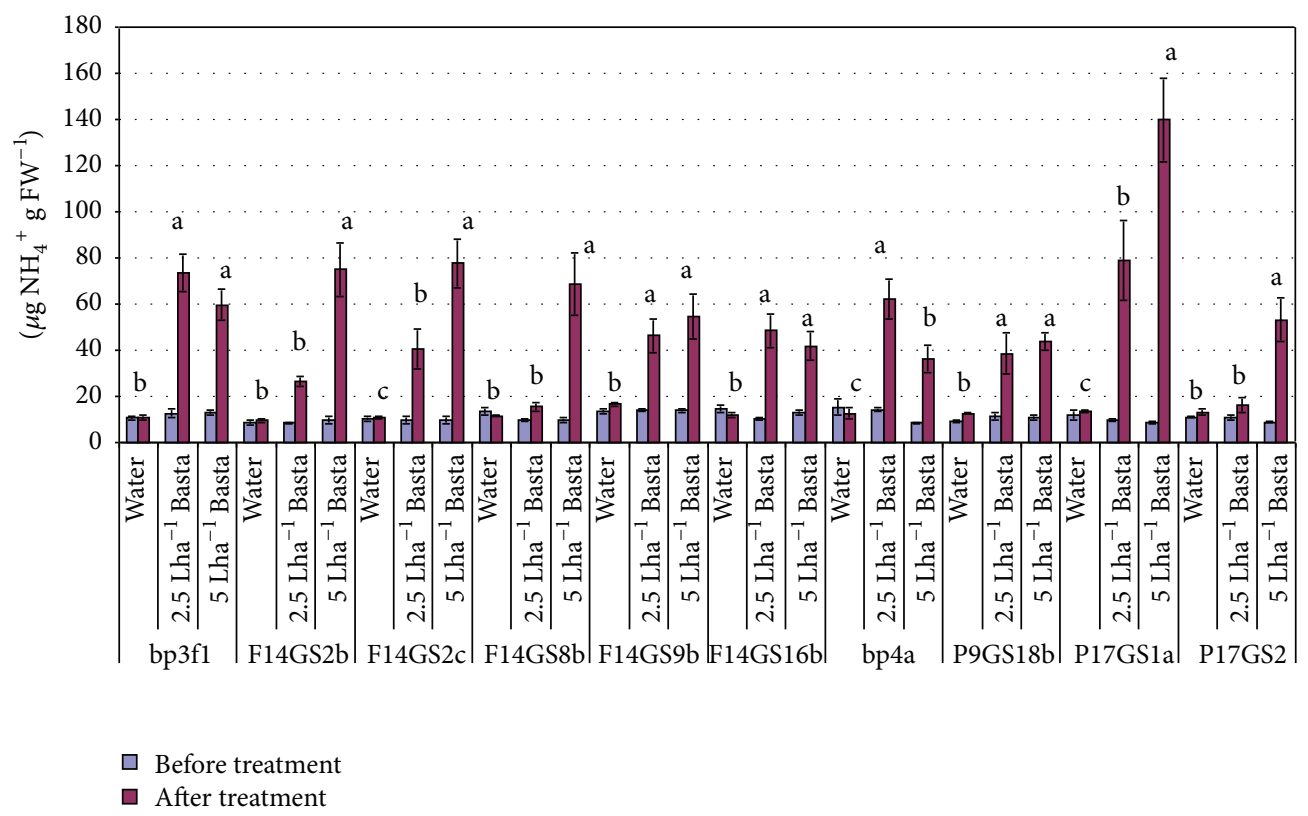

FIGURE 2: Ammonium content in birch leaf tissue before the treatment and in 3 days after the treatment. Vertical bars represent standard error. Letters indicate significance of differences at $p<0.05$ after the herbicide treatment.

transgenic lines stronger desiccation was observed, though to a lesser extent than in the case of nontransgenic control. The bp4a genotype birch plants diverged from bp3f1 ones by the water loss; a strong decrease in water content (to $23.1 \%$ ) was seen in the transgenic P17GS2 line, while in nontransgenic control line desiccation degree was similar to that in two other transgenic lines.

Estimation of the relationship between ammonium content in leaf tissue of the transgenic birch plants treated with the "Basta" herbicide at a dose equivalent to $2.5 \mathrm{Lha}^{-1}$ and their survival in 28 days after the treatment revealed lack of substantial correlation between these parameters $\left(r^{2}=0.015\right)$ (Figure 3).

\section{Discussion}

Phosphinothricin (ammonium glufosinate) is an active ingredient of a number of broad spectrum herbicides. Its target is GS, one of the main nitrogen metabolism enzymes in plants. Plants convert inorganic nitrogen into an organic one 
TABLE 1: Water content in foliar tissue of birch plants in three days after the herbicide treatment.

\begin{tabular}{ccccc}
\hline \multirow{2}{*}{ Genotype } & \multirow{2}{*}{ Line } & \multicolumn{3}{c}{ Water content after the treatment, \% } \\
& & Water & 2.5 Lha $^{-1}$ "Basta" & 5 Lha \\
& & "Basta" \\
\hline & Control & $54.8 \pm 0.5$ & $30.8 \pm 2.7^{\mathrm{b}}$ & $33.9 \pm 1.3^{\mathrm{b}}$ \\
bp3f1 & F14GS2b & $55.9 \pm 1.2$ & $43.6 \pm 1.8^{\mathrm{a}}$ & $43.7 \pm 2.2^{\mathrm{a}}$ \\
& F14GS2c & $55.2 \pm 0.6$ & $45.9 \pm 2.3^{\mathrm{a}}$ & $39.3 \pm 2.7^{\mathrm{a}}$ \\
& F14GS8b & $55.3 \pm 0.5$ & $46.9 \pm 2.0^{\mathrm{a}}$ & $42.4 \pm 1.4^{\mathrm{a}}$ \\
& F14GS9b & $52.8 \pm 1.1$ & $42.0 \pm 4.0^{\mathrm{a}}$ & $39.3 \pm 2.9^{\mathrm{a}}$ \\
& F14GS16b & $56.7 \pm 0.8$ & $41.8 \pm 2.4^{\mathrm{a}}$ & $35.5 \pm 2.2^{\mathrm{b}}$ \\
\hline \multirow{4}{*}{ bp4a } & Control & $54.4 \pm 0.7$ & $46.0 \pm 3.9^{\mathrm{a}}$ & $41.1 \pm 1.6^{\mathrm{a}}$ \\
& P9GS18b & $55.5 \pm 1.0$ & $45.8 \pm 3.0^{\mathrm{a}}$ & $47.6 \pm 4.8^{\mathrm{a}}$ \\
& P17GS1a & $57.2 \pm 0.4$ & $41.6 \pm 3.2^{\mathrm{a}}$ & $40.6 \pm 1.6^{\mathrm{a}}$ \\
& P17GS2 & $52.5 \pm 0.5$ & $30.1 \pm 2.0^{\mathrm{b}}$ & $23.1 \pm 1.0^{\mathrm{b}}$ \\
\hline
\end{tabular}

Data indicate mean \pm SE $(n=4)$.

Letters indicate significance of differences at $p<0.05$.

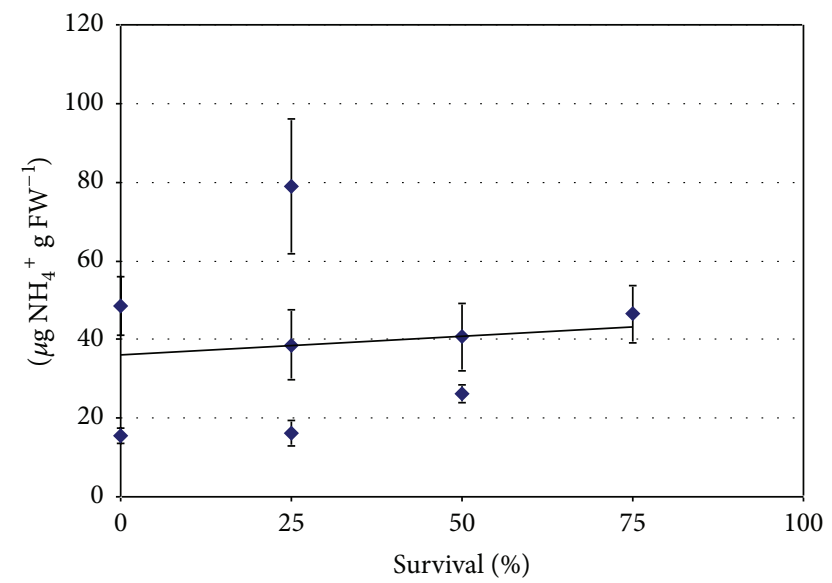

FIGURE 3: Correlation between ammonium accumulation and survival of transgenic birch plants (eight lines) after $2.5 \mathrm{Lha}^{-1}$ "Basta" treatment. Vertical bars represent standard error $(n=4)$.

via ammonium assimilation in two ways: the main, through the GS/GOGAT cycle, and the minor, through a glutamate dehydrogenase- (GDH-) catalyzed reaction [13]. Increased expression of the target enzyme GS may improve resistance to PPT. Our results demonstrate that six of eight lines containing GS transgene were slightly more resistant to PPT; in 28 days after the herbicide treatment at a $2.5 \mathrm{Lha}^{-1}$ dose (normal desiccation dose) either the shoot tip growth continued or axillary buds started growing. At the same time, untransformed plants of both genotypes died. However, after the treatment with a normal field dose $\left(5 \mathrm{Lha}^{-1}\right)$ all the plants died. Elevated PPT resistance in woody plants transformed with the GS gene either in vitro or under the greenhouse conditions was shown in a number of studies. So, Populus tremula $\times P$. alba lines carrying the pine GS1 gene demonstrated higher survivability on media with $5 \mu \mathrm{M}$ PPT as compared to control. It has been attributed to increased GS levels [14]. Sublethal dose of PPT in medium $\left(0.5 \mathrm{mgL}^{-1}\right)$ increases rooting frequency, number of roots, and their length in some aspen lines in vitro, transformed with the pine GS1 gene [4].
Treatment of 3-week-old Populus tremula $\times$ P. alba plants having the pine GS1 gene in a greenhouse with PPT at a dose equivalent to $275 \mathrm{~g} \cdot \mathrm{ha}^{-1}$ led to fall of most of leaves in both control and transgenic lines, but a net growth in transgenic plants after the treatment was 5 -fold higher [14]. However, the PPT treatment at a $500 \mathrm{~g} \cdot \mathrm{ha}^{-1}$ dose killed all plants during 3 days. All these data along with our results may indicate that additional GS gene expression slightly increases resistance to PPT, but this increase is not sufficient for commercial use of such approach. An attempt to use another nitrogen metabolism gene, glutamine dehydrogenase, to enhance the PPT resistance to tobacco plants was also unsuccessful; resistance was increased only marginally [13].

PPT irreversibly inhibits GS that leads to accumulation of ammonium in plant tissues. But what finally causes plant death is not clear, elevation of ammonium content to a toxic level or inability to synthesize nitrogen-containing compounds due to reduction of glutamine levels. In the work by Tachibana et al. [7], about 30 to 100 times' increase in ammonium content after the PPT treatment of several plant species and a close correlation between herbicide activity and ammonium levels were demonstrated. At the same time, addition of glutamine did not affect substantially the herbicide activity of PPT [15]. On the other hand, addition of glutamine and glutamate to PPT reduced the photosynthesis inhibition in Sinapis alba; that is, the $\mathrm{NH}_{4}^{+}$accumulation cannot be the primary cause for photosynthesis inhibition by PPT [8]. Addition of glutamine also overcame a negative effect of PPT on hairy root growth in Brassica napus [16]. Analogous studies were not performed on woody species. It is only known that, in 24 hours after treatment of Populus alba $\times$ $P$. tremula hybrid with the "Basta" herbicide at a dose of $20 \mathrm{Lha}^{-1}$, ammonium levels elevated almost 100 times, from 9 to $800-900 \mu \mathrm{g} \mathrm{NH}_{4}{ }^{+} \mathrm{g} \mathrm{FW}^{-1}$ [17]. In our work, $\mathrm{NH}_{4}{ }^{+}$content in control birch plants increased 4.8-5.8 times only (to $73.6 \mu \mathrm{g} \mathrm{NH}_{4}{ }^{+} \mathrm{g} \mathrm{FW}^{-1}$ ). Relatively low increase in $\mathrm{NH}_{4}{ }^{+}$content in our work may have several reasons: first, a significantly higher herbicide dose in the study of De Block [17] than in our work: 4 and $1.5 \mathrm{~kg} \cdot \mathrm{ha}^{-1} \mathrm{PPT}$, respectively. Second, tens of times' greater $\mathrm{NH}_{4}{ }^{+}$accumulation was observed in $24 \mathrm{~h}$ after the treatment, while we took measurements in 3 days. Probably, in our case peak of the $\mathrm{NH}_{4}{ }^{+}$accumulation was passed and its levels were reduced already. It is indirectly confirmed by the fact that $\mathrm{NH}_{4}{ }^{+}$levels in nontransgenic plants were higher after the treatment with $2.5 \mathrm{Lha}^{-1}$ than after higher dose of $5 \mathrm{Lha}^{-1}$. It is possible that $\mathrm{NH}_{4}{ }^{+}$accumulation and a decrease of its levels were delayed as compared to the higher dose. This phenomenon was not observed in GS containing lines, which may indicate that GS expression prevented such fast $\mathrm{NH}_{4}{ }^{+}$accumulation as in nontransgenic plants. Finally, metabolic processes may occur more intensively in young plants grown in a greenhouse, while in our experiments plants were older and were grown under open air conditions. Pornprom et al. [18] reported that $\mathrm{NH}_{4}{ }^{+}$levels in field-grown corn plants treated with "Basta" at doses similar to ours in 3 days have only increased by about $40-70 \%$, and only in 14 days were they as much as $2-5$ times as in control plants. 
A PPT treatment of the Populus tremula $\times$ P. alba hybrid led to a fall of majority of leaves in both control and transgenic plants, though they further diverged from each other in growth rate [14]. In our report, damage symptoms of leaf tissue did not reflect biochemical processes in birch plants after the herbicide treatment. Extent of leaf necrosis was similar in both control and transgenic plants irrespectively of the PPT dose. Meanwhile, after the $2.5 \mathrm{Lha}^{-1}$ treatment in the similarly damaged leaves ammonium levels varied over a wide range, from 15.5 to $78.9 \mu \mathrm{g} \mathrm{NH}_{4}^{+} \mathrm{g} \mathrm{FW}^{-1}$; and in three transgenic lines $\mathrm{NH}_{4}{ }^{+}$content did not differ from that of a control water-treated variant (Figure 2). This may indicate an increased resistance to PPT in plants containing the additional GS gene. Decreased (comparing to control) accumulation of $\mathrm{NH}_{4}{ }^{+}$was also observed in hairy root Brassica napus cultures carrying a gene for soybean cytosolic GS enzyme: in a transgenic line, ammonium content increased from 0.03 to $0.12 \mu \mathrm{g} \mathrm{NH}_{4}{ }^{+} \mathrm{g} \mathrm{DW}^{-1}$ at $100 \mu \mathrm{M} \mathrm{PPT}$, while the increase was from 0.08 to $0.25 \mu \mathrm{g} \mathrm{NH}_{4}{ }^{+} \mathrm{g} \mathrm{DW}^{-1}$ in control (WT) [19]. All these results may suppose neutralization PPT applied at low doses by an increased GS gene expression. However our research demonstrated no correlation between ammonium accumulation in transgenic birch lines treated with $2.5 \mathrm{Lha}^{-1}$ and their survival 28 days after the herbicide application (Figure 3). For instance, all the F14GS8b plants have died $\left(15.5 \mu \mathrm{g} \mathrm{NH}_{4}{ }^{+} \mathrm{g} \mathrm{FW}^{-1}\right)$, while three of four F14GS9b line plants $\left(46.4 \mu \mathrm{g} \mathrm{NH}_{4}^{+} \mathrm{g} \mathrm{FW}^{-1}\right)$ survived.

For assessment of plant sensitivity to PPT, such parameter as decrease of fresh $[7,15]$ or dry weight $[13]$ was used. Since the "Basta" herbicide is also used as desiccant, we decided to use index of desiccation of foliar tissue. This method is advantageous as it does not require elimination of native plant. Water content in control plats of bp3f1 genotype dropped from 55 to $31-34 \%$; that is, the fresh weight decreased by half. Reduction of water levels in tissues of most of the transgenic lines after the treatment with $2.5 \mathrm{Lha}^{-1}$ was approximately equal (to $42-47 \%$ ) and substantially lower comparing to nontransgenic control. Desiccation after the treatment with $5 \mathrm{Lha}^{-1}$ dose was also lower in transgenic lines than in the bp3f1 control. However, P17GS2 line was featured by very strong desiccation, while water loss in nontransgenic bp4a genotype plants was equal to that in transgenic lines containing the GS gene. Probably, particularities of this genotype are the reason for such differences.

\section{Conclusions}

We found that transfer of a pine gene encoding cytosolic form of the glutamine synthetase slightly increased in resistance of birch plants to PPT, but such increase is not sufficient for commercial use of this approach. Our data allow suggesting that in birch plants free ammonium toxicity is not the primary reason for their death after the PPT treatment, as the ammonium accumulation did not correlate with survival of plants. Apparently, death of birch plants after the PPT treatment is not determined by the critical ammonium accumulation, but rather by other factors, in particular, by interference with amino acid biosynthesis and, first of all, glutamine biosynthesis.

\section{Conflict of Interests}

The authors declare that there is no conflict of interests regarding the publication of this paper.

\section{Acknowledgment}

This work is supported by the Ministry of Education and Science of the Russian Federation (Project no. 14.616.21.0013 from 17.09.2014, unique identifier RFMEFI61614X0013).

\section{References}

[1] M. Pihlatie, J. Pumpanen, and P. Hari, " $\mathrm{N}_{2} \mathrm{O}$ emissions from boreal forest," in Boreal Forest and Climate Change, P. Hari and L. Kulmala, Eds., vol. 34 of Advances in Global Change Research, pp. 504-506, Springer, Dordrecht, The Netherlands, 2008.

[2] R. J. Ireland and P. J. Lea, "The enzymes of glutamine, glutamate, asparagines, and aspartate metabolism," in Plant Amino Acids. Biochemistry and Biotechnology, B. K. Singh, Ed., pp. 49-109, Marcel Dekker, New York, NY, USA, 1999.

[3] F. Gallardo, J. Fu, F. R. Cantón, A. García-Gutiérrez, F. M. Cánovas, and E. G. Kirby, "Expression of a conifer glutamine synthetase gene in transgenic poplar," Planta, vol. 210, no. 1, pp. 19-26, 1999.

[4] K. A. Shestibratov, I. V. Bulatova, and P. S. Novikov, "In vitro response of transgenic aspen containing glutamine synthetase gene GSI to the sublethal dose of phosphinothricin," Applied Biochemistry and Microbiology, vol. 46, no. 8, pp. 763-768, 2010.

[5] E. González, C. Gugliermoni, M. Galvão et al., "Characterization of herbicide-resistant Eucalyptus plants expressing phosphinothricin acetyltransferase gene," BMC Proceedings, vol. 5, supplement 7, article P135, 2011.

[6] P. J. Lea and S. M. Ridley, "Glutamine synthetase and its inhibition," in Herbicides and Plant Metabolism, A. D. Dodge, Ed., vol. 38 of Society for Experimental Biology Seminar Series, pp. 137-170, Cambridge University Press, Cambridge, UK, 1989.

[7] K. Tachibana, T. Watanabe, Y. Sekizawa, and T. Takematsu, "Accumulation of ammonia in plants treated with bialaphos," Journal of Pesticide Science, vol. 11, no. 1, pp. 33-37, 1986.

[8] C. Wendler, M. Barniske, and A. Wild, "Effect of phosphinothricin (glufosinate) on photosynthesis and photorespiration of C3 and C4 plants," Photosynthesis Research, vol. 24, no. 1, pp. 55-61, 1990.

[9] V. G. Lebedev, K. A. Schestibratov, T. E. Shadrina, I. V. Bulatova, D. G. Abramochkin, and A. I. Miroshnikov, "Cotransformation of aspen and birch with three T-DNA regions from two different replicons in one Agrobacterium tumefaciens strain," Russian Journal of Genetics, vol. 46, no. 11, pp. 1282-1289, 2010.

[10] S. Chang, J. Puryear, and J. A. Cairney, "A simple and efficient method for isolating RNA from pine trees," Plant Molecular Biology Reporter, vol. 11, no. 2, pp. 113-116, 1993.

[11] M. De Block, D. De Brouwer, and P. Tenning, "Transformation of Brassica napus and Brassica oleracea using Agrobacterium tumefaciens and the expression of the bar and neo genes in the transgenic plants," Plant Physiology, vol. 91, no. 2, pp. 694-701, 1989. 
[12] M. W. Weatherburn, "Phenol-hypochlorite reaction for determination of ammonia," Analytical Chemistry, vol. 39, no. 8, pp. 971-974, 1967.

[13] S. A. Nolte, B. G. Young, R. Mungur, and D. A. Lightfoot, "The glutamate dehydrogenase gene $g d h A$ increased the resistance of tobacco to glufosinate," Weed Research, vol. 44, no. 4, pp. 335339, 2004.

[14] M. B. Pascual, Z. P. Jing, E. G. Kirby, F. M. Cánovas, and F. Gallardo, "Response of transgenic poplar overexpressing cytosolic glutamine synthetase to phosphinothricin," Phytochemistry, vol. 69, no. 2, pp. 382-389, 2008.

[15] K. Tachibana, T. Watanabe, Y. Sekizawa, and T. Takematsu, "Inhibition of glutamine synthetase and quantitative changes of free amino acids in shoots of bialaphos-treated Japanese barnyard millet," Journal of Pesticide Science, vol. 11, no. 1, pp. 27-31, 1986.

[16] C. G. Downs, M. C. Christey, D. Maddocks, J. F. Seelye, and D. G. Stevenson, "Hairy roots of Brassica napus: I. Applied glutamine overcomes the effect of phosphinothricin treatment," Plant Cell Reports, vol. 14, no. 1, pp. 37-40, 1994.

[17] M. De Block, "Factors influencing the tissue culture and the Agrobacterium tumefaciens-mediated transformation of hybrid aspen and poplar clones," Plant Physiology, vol. 93, no. 3, pp. 1110-1116, 1990.

[18] T. Pornprom, J. Chompoo, and B. Grace, "Glufosinate tolerance in hybrid corn varieties based on decreasing ammonia accumulation," Weed Biology and Management, vol. 3, no. 1, pp. 41-45, 2003.

[19] C. G. Downs, M. C. Christey, K. M. Davies et al., "Hairy roots of Brassica napus: II. Glutamine synthetase overexpression alters ammonia assimilation and the response to phosphinothricin," Plant Cell Reports, vol. 14, no. 1, pp. 41-46, 1994. 

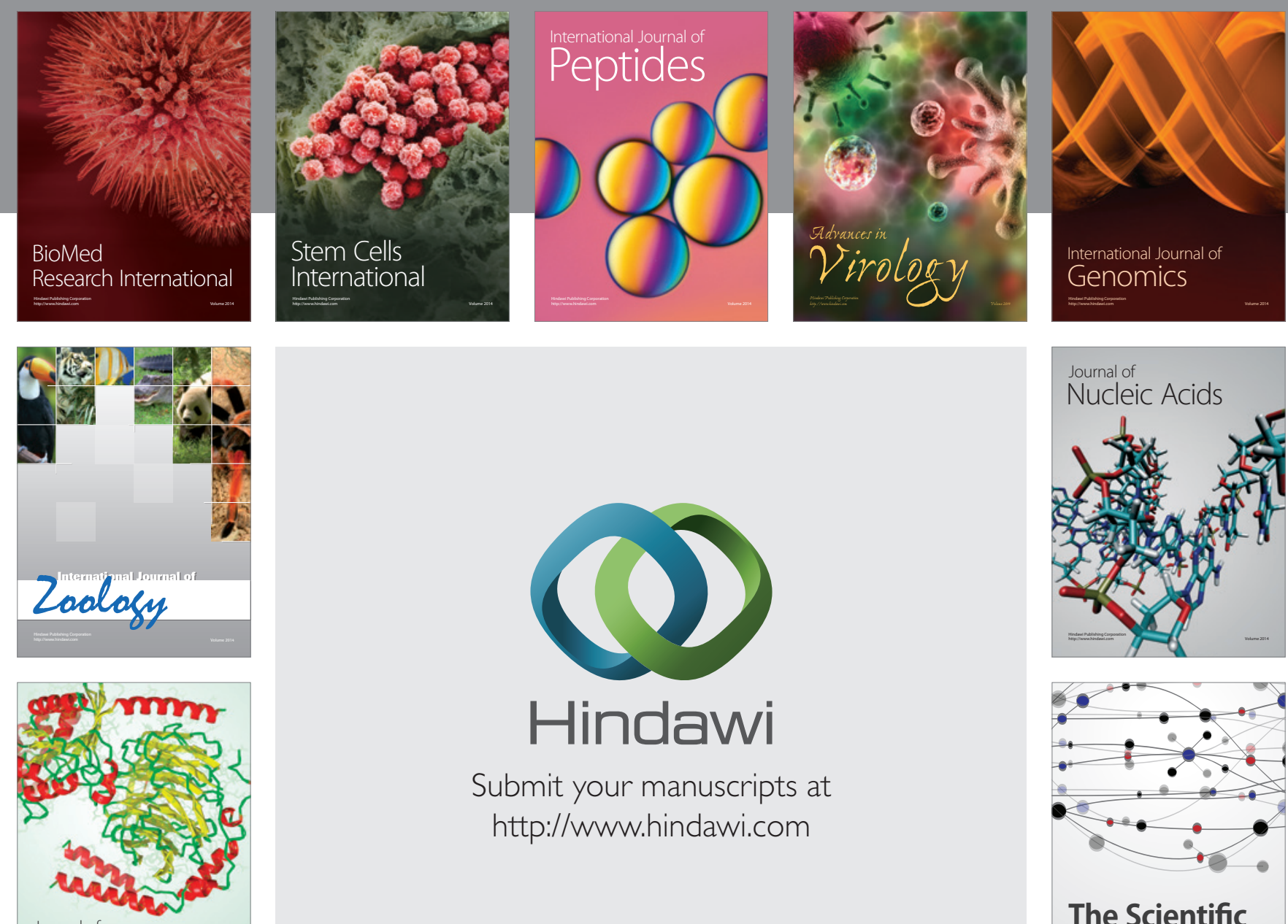

Submit your manuscripts at

http://www.hindawi.com

Journal of
Signal Transduction
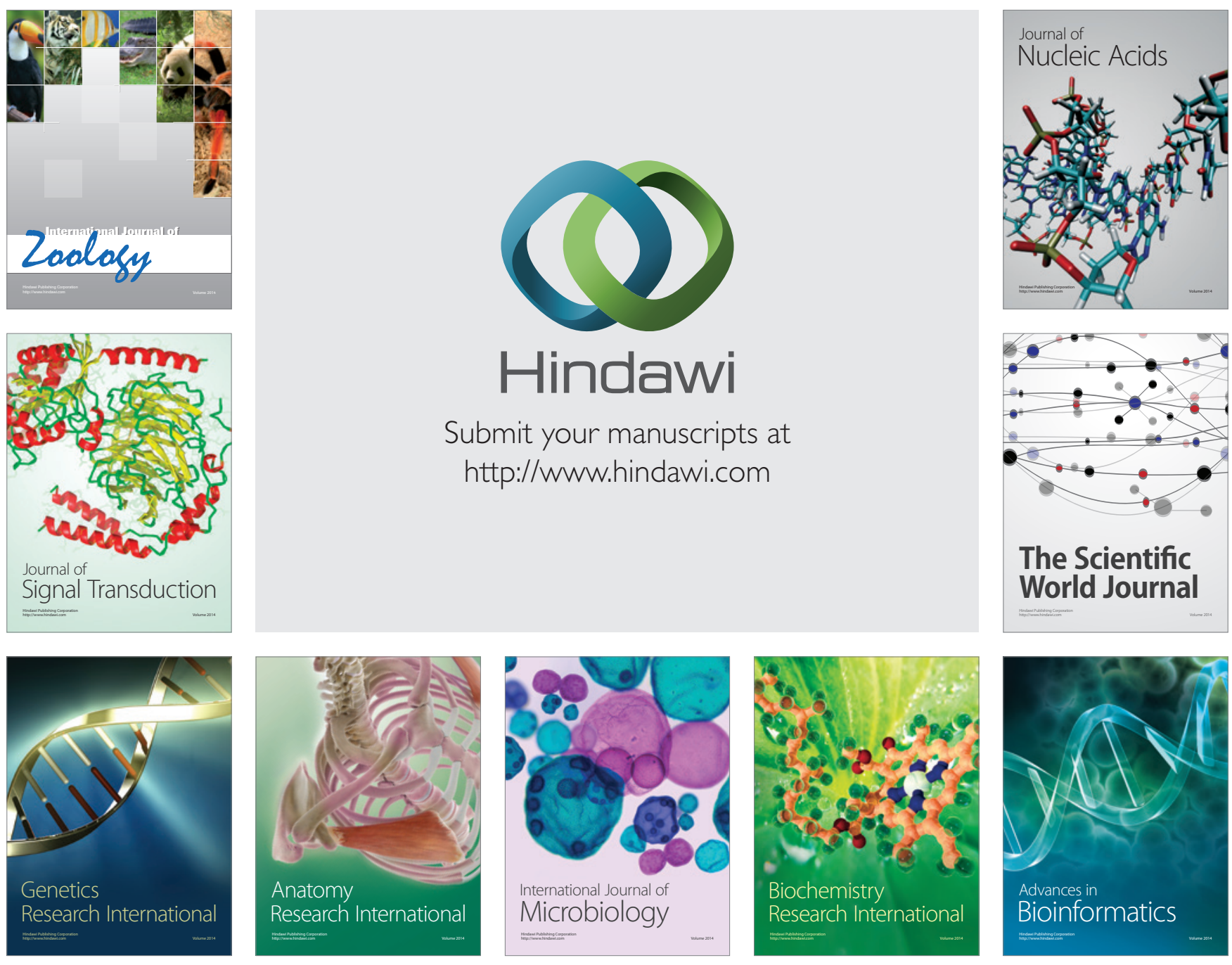

The Scientific World Journal
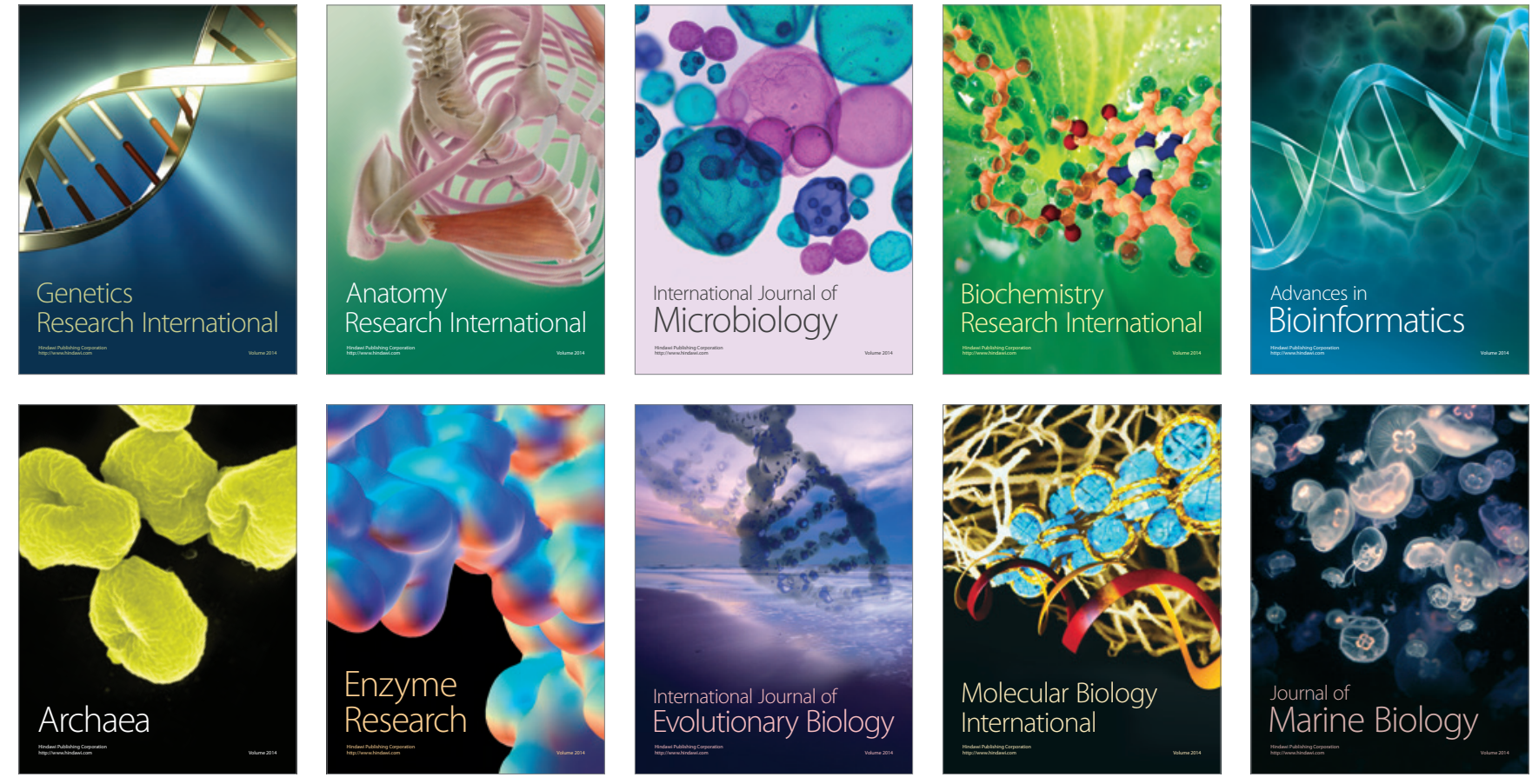